\title{
Assessment of Teachers' Knowledge Related to Cervical Cancer at Secondary Schools in Baghdad City
}

\author{
*Sarah Abd Hlhussen, M. Sc. **Prof. Dr. Iqbal Majeed Abbas, PhD \\ * Maternal \& Neonate Health Nursing Department, College of Nursing, University of Baghdad, Iraq. \\ * * Professor, Maternal and Neonate Nursing Department, College of Nursing, University of Baghdad, Iraq
}

\begin{abstract}
:
Back ground: cervical cancer is the second most common cancer among women worldwide. Cervical cancer if detected early is one of the most preventable cancers because of its slow progression, cytological identifiable precursors, and effective treatments. It is important to be aware teachers of the facts about cervical cancer and especially of screening techniques which can be utilized in low-resource settings

Objectives: To assess knowledge among study sample related to cervical cancer and find out relationship between teacher's knowledge and studied variables.

Methodology: Non- experimental (descriptive design) was conducted at secondary school in Baghdad city among teacher on A non-probability (purposive sample) of $(N=80)$ women. This study started from 27 May to 27 June 2016. The data were collected through the questionnaire, which consists of two parts (A) Socio-demographic and reproductive data, (B) knowledge items (52) related cervical cancer which are measured by dichotomous scale (Yes and No) and rated as follow: No=1 and Yes=2, so the cutoff point $=1.5$. Content validity for the instrument was determined through the use of panel experts to investigate the clarity, relevancy, and adequacy of the questionnaire in order to achieve the present study's objectives. The internal consistency of the instrument was determined through the pilot study and the computation of Alpha Correlation Coefficient (Cronbach's Alpha). The result of the reliability was statistically adequate. All teachers are interviewed, and each one was given a time period between (15-20) minutes to answer the questions. The data were analyzed by using the Statistical Package for Social Sciences (20.0), a descriptive and inferential statistics applications were used for the analysis of data.
\end{abstract}

Results: The study shows that the highest percentage (37.5\%) their age was ranged between (21-30) years. The highest percentages (85\%) were from urban area. The highest percentage (85\%) was married. The highest percentage (80\%) was graduated from college. The highest percentage $(67.5 \%)$ had enough in some extend their economic status. The highest percentage (60\%) had 2-4 pregnancies. The highest percentage $(52.5 \%)$ had (2-4) parity. And the items of knowledge related to cervical cancer shows that below cut-of-point (1.5) for all items indicated that the teachers have inadequate knowledge toward cervical cancer. The study shows that teachers' knowledge is associated significantly with residence and their husband's level of education at p-value $\leq 0.05$. And there are high significant association between teachers' knowledge and their number of gravida, number of para, and place of previous delivery at p-value $\leq 0.001$. Number of abortion also shows significant association with teachers' knowledge at p-value $\leq 0.01$, while there is no significant association between teachers' knowledge with remaining variables.

Conclusion: The study was concluded that most of the items of knowledge related to cervical cancer below cutof-point (1.5).

Recommendations: Increase women awareness of cervical cancer through mass media. Establish a lectures or courses to raise awareness of teacher's at secondary school about cervical cancer.

Keywords: Cervical cancer, Secondary Schools, Teachers' knowledge

\section{Introduction}

Cervical cancer is as a result of Human Papillomavirus which is transmitted through sexual intercourse, in most cases the male is a career of the papilloma virus that infects and generates in females. Despite risks of the HPV virus both males and females are hardly aware of the virus and the risks it carries ${ }^{(\mathbf{1})}$. Cervical cancer is one of the most preventable cancers because of its slow progression, cytologically identifiable precursors, and effective treatments. Therefore, the key to reducing Cancer morbidity and mortality is the early detection and treatment of pre-cancerous lesions. Through Screening, women with asymptomatic pre-invasive lesions can be identified and the progress can be halted. Papanicolaou (Pap) test also known as cervical cytology screening has helped to reduce cervical cancer rates dramatically through detect ion of premalignant lesions ${ }^{(2)}$. Cancer fatalism has continued to increase among especially young women, this is the belief that women have had that diagnosis of cancer directly translates to inevitable death therefore they find it better to avoid going for screening and are with no knowledge related to their health . Education and Knowledge on both breast cancer 
and cervical cancer has continued to decrease as the cancer fatalism increases not because there is no available information but because the women have been ignorant to enlighten themselves ${ }^{(3)}$. The cervix is composed of columnar epithelium, which lines the end cervical canal, and squamous epithelium, which covers the exocervix. The point at which they meet is called the squamocolumnar junction. Metaplasia advances from the original squamocolumnar junction inwards toward the external os and over the columnar villi, which establishes an area called the transformation zone. Screening with conventional Pap testing should occur every year. If liquid-based cytology (LBC) is being used, screening can be extended to every 2 years. Screening should begin at the age of 21 or within 3 years of the onset of sexual activity and it can stop at the age of 70 years if there has been no abnormal Pap test result in the past 10 years ${ }^{(4)}$.

\section{Methodology}

A descriptive design was carried throughout the present study to assess Teacher's Knowledge related to cervical cancer at Secondary School in Baghdad City. This study started from May 27, 2016 to Jun 272016. The sample was selected with method of non-probability sampling (purposive sample) that consist of (80) women teachers from secondary schools. The questionnaire of the study was constructed for the purpose of this study by reviewing the previous studies concerning the knowledge about cervical cancer. The constructed questionnaire is consists of two parts; the first part was consists the demographic characteristics of the sample; the second part is includes the items related to knowledge about cervical cancer, these items were (52) which are measured by dichotomous scale (Yes and $\mathrm{No}$ ) and rated as follow: $\mathrm{No}=1$ and $\mathrm{Yes}=2$, so the cutoff point $=1.5$. Content validity for the instrument was determined through the use of panel experts to investigate the clarity, relevancy, and adequacy of the questionnaire in order to achieve the present study's objectives. The internal consistency of the instrument was determined through the pilot study and the computation of Alpha Correlation Coefficient (Cronbach's Alpha). The result of the reliability was statistically adequate. All teachers are interviewed, and each one was given a time period between (15-20) minutes to answer the questions. The data were analyzed by using the Statistical Package for Social Sciences (20.0), a descriptive and inferential statistics applications were used for the analysis of data.

\section{Results}

Table (1): Distribution of the Sample according to their Socio-demographic variables $(\mathrm{N}=80)$

\begin{tabular}{|c|c|c|c|c|}
\hline No. & \multicolumn{2}{|c|}{ Socio-demographic variables } & F. & $\%$ \\
\hline \multirow[t]{4}{*}{1} & \multirow[t]{4}{*}{ Age/years } & $21-30$ year & 30 & 37.5 \\
\hline & & $31-40$ year & 24 & 30 \\
\hline & & $41-50$ year & 14 & 17.5 \\
\hline & & $51 \leq$ year & 12 & 15 \\
\hline \multirow[t]{2}{*}{2} & \multirow[t]{2}{*}{ Residence: } & Urban & 68 & 85 \\
\hline & & Rural & 12 & 15 \\
\hline \multirow[t]{5}{*}{3} & \multirow[t]{5}{*}{ Marital Status: } & Married & 68 & 85 \\
\hline & & Divorced & 2 & 2.5 \\
\hline & & Widowed & 10 & 12.5 \\
\hline & & Institute graduate & 16 & 20 \\
\hline & & College graduate & 64 & 80 \\
\hline \multirow[t]{4}{*}{5} & \multirow[t]{4}{*}{ Husband's Education: } & Primary School Graduated & 20 & 25 \\
\hline & & Secondary School Graduated & 34 & 42.5 \\
\hline & & Institute Graduated & 8 & 10 \\
\hline & & College Graduated & 18 & 22.5 \\
\hline \multirow[t]{3}{*}{6} & \multirow[t]{3}{*}{ Monthly Income: } & Enough & 16 & 20 \\
\hline & & Enough in some extend & 54 & 67.5 \\
\hline & & Not enough & 10 & 12.5 \\
\hline
\end{tabular}

F: Frequency, \%: Percentage

This table indicated that teachers is between age groups of 21-30 years (37.5\%), and shows the highest percentage $(85 \%)$ is married and the highest percentage resident in an urban area is $(85 \%)$. And the highest percentage $(80 \%)$ of teachers are graduated from college, while the highest percentage $(42.5 \%)$ their husbands are graduated from secondary school .Regarding monthly income the highest percentage is (67.5\%) are reported barely sufficient income

Table (2): Distribution of the Sample Regarding their Reproductive variables $(\mathrm{N}=80)$

\begin{tabular}{|l|l|l|l|l|}
\hline No. & Reproductive Variables & F & \% \\
\hline 1 & \multirow{2}{*}{ Number of gravida: } & One & 24 & 30 \\
\cline { 3 - 5 } & & $2-4$ & 48 & 60 \\
\cline { 3 - 5 } & & $5 \leq$ & 8 & 10 \\
\hline 2 & Number of Para: & None & 2 & 2.5 \\
\cline { 3 - 5 } & & One & 32 & 40 \\
\hline
\end{tabular}




\begin{tabular}{|l|l|l|l|l|}
\hline \multirow{2}{*}{3} & $2-4$ & 42 & 52.5 \\
\cline { 3 - 5 } & \multirow{2}{*}{ Number of abortion: } & $5 \leq$ & 14 & 5 \\
\cline { 3 - 5 } & & None & 66 & 82.5 \\
\hline \multirow{2}{*}{4} & \multirow{2}{*}{ Number of stillbirth: } & One & 14 & 17.5 \\
\cline { 3 - 5 } & & One & 60 & 74 \\
\cline { 3 - 5 } & & $2-4$ & 2 & 22.5 \\
\hline 5 & \multirow{2}{*}{ Number of alive child: } & None & 2 & 2.5 \\
\cline { 3 - 5 } & & $1-3$ & 70 & 2.5 \\
\cline { 3 - 5 } & & $4-6$ & 6 & 87.5 \\
\cline { 3 - 5 } & & $7 \leq$ & 2 & 7.5 \\
\hline 6 & \multirow{2}{*}{ Place of previous delivery: } & At Hospital & 76 & 2.5 \\
\cline { 3 - 5 } & & At House & 4 & 5 \\
\hline 7 & \multirow{2}{*}{ Type of delivery: } & Cesarean section & 16 & 20 \\
\cline { 3 - 5 } & & $\begin{array}{l}\text { Normal vaginal } \\
\text { delivery }\end{array}$ & 64 & 80 \\
\hline
\end{tabular}

\section{F: Frequency, \%: Percentage}

This table revealed the reproduction-related characteristics; $60 \%$ of teachers have 2-4 gravida., More of teachers have no abortion (82.5\%) and only $17.5 \%$ of them having one abortion. $74 \%$ of them having stillbirth and more of them having 1-3 alive child (87.5\%). Most of them shows that they have delivery at hospital (95\%) and more of them were normal vaginal delivery $(80 \%)$

Table (3): Teachers' Knowledge toward Cervical Cancer ( $\mathrm{N}=80)$

\begin{tabular}{|c|c|c|c|c|}
\hline \multirow[t]{2}{*}{ No. } & \multirow[t]{2}{*}{ Teachers' Knowledge toward Cervical Cancer } & \multirow{3}{*}{$\begin{array}{l}\text { Yes } \\
\text { F. }(\%)\end{array}$} & \multirow{3}{*}{$\begin{array}{l}\text { No } \\
\text { F. }(\%)\end{array}$} & \multirow[t]{3}{*}{ MS } \\
\hline & & & & \\
\hline I & Anatomy and physiology of cervix. & & & \\
\hline 1 & $\begin{array}{l}\text { It is a Canal-like, and connects with body of the uterus at the internal } \\
\text { os and descends about } 2.5 \mathrm{~cm} \text { to connect with vagina at the external } \\
\text { os. }\end{array}$ & $24(30)$ & $56(70)$ & 1.3 \\
\hline 2 & The vaginal and cervix appear pink & $16(20)$ & $64(80)$ & 1.2 \\
\hline 3 & $\begin{array}{l}\text { Cervix has the ability to stretch due to the high fibers and } \\
\text { collagenous }\end{array}$ & $0(0)$ & $80(100)$ & 1 \\
\hline 4 & To lubricate the vaginal canal & $8(10)$ & $72(90)$ & 1.1 \\
\hline 5 & To act as bacteriostatic & $24(30)$ & $56(70)$ & 1.3 \\
\hline 6 & To provide an alkaline environment for the sperm. & $16(20)$ & $64(80)$ & 1.2 \\
\hline \multicolumn{5}{|c|}{ Grand mean $=1.1$} \\
\hline II & Signs and symptoms related to cervical cancer & & & \\
\hline 1 & Lower Back pain & $8(10)$ & $72(90)$ & 1.1 \\
\hline 2 & Bleeding between cycle & $8(10)$ & $72(90)$ & 1.1 \\
\hline 3 & Offensive odder of discharge & $8(10)$ & $72(90)$ & 1.1 \\
\hline \multicolumn{5}{|c|}{ Grand mean $=1.1$} \\
\hline III & Risk factors related to cervical cancer & & & \\
\hline 1 & The HPV cause cervical cancer & $24(30)$ & $56(70)$ & 1.3 \\
\hline 2 & Skin abscesses & $8(10)$ & $72(90)$ & 1.1 \\
\hline 3 & Causing genital warts & $24(30)$ & $56(70)$ & 1.3 \\
\hline 4 & Positive and negative smoking & $16(20)$ & $64(80)$ & 1.2 \\
\hline 5 & Hormonal contraceptive methods used. & $8(10)$ & $72(90)$ & 1.1 \\
\hline 6 & Life style for nutrition & $24(30)$ & $56(70)$ & 1.3 \\
\hline 7 & Woman need papanicolaou after menopause & $0(0)$ & $80(100)$ & 1 \\
\hline 8 & Pap used even after HPV vaccine & $8(10)$ & $72(90)$ & 1.1 \\
\hline 9 & Pap is method of cervical cancer prevention & $8(10)$ & $72(90)$ & 1.1 \\
\hline 10 & Routine pap smear is the method of cervical cancer prevent & $24(30)$ & $56(70)$ & 1.3 \\
\hline 11 & Pap detect infection of reproductive system & $16(20)$ & $64(80)$ & 1.2 \\
\hline \multicolumn{5}{|c|}{ Grand mean $=1.1$} \\
\hline IV & Knowledge regarding colposcopy & & & \\
\hline 1 & $\begin{array}{l}\text { Colposcopy view the cervical cells throw out insert magnitude lens } \\
\text { via vagina }\end{array}$ & $16(40)$ & $64(80)$ & 1.2 \\
\hline 2 & $\begin{array}{l}\text { First objective to the colposcopy is to search for precancerous cells } \\
\text { that pap smear diagnosis a signs of abnormalities of epithelial in the } \\
\text { cervix }\end{array}$ & $16(40)$ & $64(80)$ & 1.2 \\
\hline 3 & Using speculum to open vagina and observe cervix & $32(40)$ & $48(60)$ & 1.4 \\
\hline 4 & $\begin{array}{l}\text { Using iodine to stained the every normal cells expect the carcinoma } \\
\text { cells }\end{array}$ & $24(30)$ & $56(70)$ & 1.3 \\
\hline 5 & Using acetic acid that make change including acetowhite epithelium & $24(30)$ & $56(70)$ & 1.3 \\
\hline 6 & Avoid sexual intercourse 48 hours before pap smear & $32(40)$ & $48(60)$ & 1.4 \\
\hline 7 & Avoid using vaginal suppositories to rise 48 hourse before pap smear & $24(30)$ & $56(70)$ & 1.3 \\
\hline 8 & Avoid vaginal doush before pap smear & $24(30)$ & $56(70)$ & 1.3 \\
\hline 9 & avoid using vaginal creams before pap smear & $24(30)$ & $56(70)$ & 1.3 \\
\hline
\end{tabular}




\begin{tabular}{|c|c|c|c|c|}
\hline \multicolumn{5}{|c|}{ Grand mean $=1.3$} \\
\hline $\mathbf{V}$ & Knowledge regarding to pap smear & & & \\
\hline 1 & Did you hear about procedure papanicolaou smear & $24(30)$ & $56(70)$ & 1.3 \\
\hline 2 & Did you performing papanicolaou smear procedure & $8(10)$ & $72(90)$ & 1.1 \\
\hline 3 & Know in related to age performing & $8(10)$ & $72(90)$ & 1.1 \\
\hline 4 & Purpose of pap to detect precarcenoma cells (Possible) & $8(10)$ & $72(90)$ & 1.1 \\
\hline 5 & Purpose of pap to detect precarcenoma cells (Impossible) & $8(10)$ & $72(90)$ & 1.1 \\
\hline \multicolumn{5}{|c|}{ Grand mean $=1.3$} \\
\hline VI & Barriers for not implement pap smear & & & \\
\hline 1 & Lack of knowledge & $16(40)$ & $64(80)$ & 1.2 \\
\hline 2 & Afraid for doing pap & $0(0)$ & $80(100)$ & 1 \\
\hline 3 & Don't have time for perform pap smear & $8(10)$ & $72(90)$ & 1.1 \\
\hline 4 & Pap smear is expensive & $8(10)$ & $72(90)$ & 1.1 \\
\hline 5 & Benefit for implantation of pap smear & $8(10)$ & $72(90)$ & 1.1 \\
\hline 6 & Did papanicolaou scraping cervical cells & $8(10)$ & $72(90)$ & 1.1 \\
\hline 7 & Pap smear able to detect precancerous cells & $0(0)$ & $80(100)$ & 1 \\
\hline 8 & Pap smear detect the fibroid tumor & $0(0)$ & $80(100)$ & 1 \\
\hline 9 & Pap smear reduce mortality and morbidity due to cervical cancer & $0(0)$ & $80(100)$ & 1 \\
\hline 10 & Starting pap smear at the onset of marriage & $0(0)$ & $80(100)$ & 1 \\
\hline 11 & Pap smear starting at age 21 years for married woman & $0(0)$ & $80(100)$ & 1 \\
\hline 12 & Perform pap smear every 3 years for the reproductive age & $8(10)$ & $72(90)$ & 1.1 \\
\hline 13 & Avoiding smoking weather negative or positive & $8(10)$ & $72(90)$ & 1.1 \\
\hline 14 & Eating balance diet for maintain woman's health & $16(40)$ & $64(80)$ & 1.2 \\
\hline 15 & Performing pap test regularly even in well health & $0(0)$ & $80(100)$ & 1 \\
\hline \multirow[t]{2}{*}{16} & HPV Vaccination in case of availability & $24(30)$ & $56(70)$ & 1.3 \\
\hline & \multicolumn{4}{|c|}{ Grand mean $=1.1$} \\
\hline
\end{tabular}

\section{F: Frequencies, MS:Mean of Score}

This table presents the mean of scores for the items of knowledge toward cervical cancer, the mean of score indicated below cut -off-point( 1.5) for all items indicated that teachers have no knowledge toward cervical cancer.

Table (4) The Relationship between Teachers' Knowledge and Their Socio-demographic variables (N=80)

\begin{tabular}{|l|l|l|l|l|}
\hline Variables Chi-Square & $\mathbf{X}^{\mathbf{2}}$ & $\mathbf{d . f}$ & P-Value & Significance \\
\hline Age & 26.690 & 10 & 0.181 & $\mathrm{NS}$ \\
\hline Residence & 15.294 & 2 & 0.032 & $\mathrm{~S}$ \\
\hline Marital status & 17.412 & 4 & 0.235 & $\mathrm{NS}$ \\
\hline Teacher's educational level & 9.688 & 2 & 0.297 & $\mathrm{NS}$ \\
\hline Husband's educational level & 34.699 & 6 & 0.030 & $\mathrm{~S}$ \\
\hline Monthly income & 20.269 & 4 & 0.122 & $\mathrm{NS}$ \\
\hline Number of gravida & 85.250 & 12 & 0.001 & $\mathrm{HS}$ \\
\hline Number of para & 102.333 & 12 & 0.001 & $\mathrm{H} . \mathrm{S}$ \\
\hline Number of abortion & 19.394 & 2 & 0.01 & $\mathrm{~S}$ \\
\hline Number of stillbirth & 16.778 & 4 & 0.268 & $\mathrm{NS}$ \\
\hline Place of previous delivery & 85.917 & 12 & 0.001 & $\mathrm{HS}$ \\
\hline Type of delivery & 11.579 & 4 & 0.115 & $\mathrm{NS}$ \\
\hline
\end{tabular}

\section{$\mathrm{X}^{2}$ : Chi-square, d.f: Degree of freedom, N.S: Not significant, S: Significant, HS:High Significant}

This table reveals that there is high significant association between teachers' knowledge and their number of gravida, number of para, and place of previous delivery at $p$-value $\leq 0.001$. And teachers' knowledge is associated significantly with residence and their husband's level of education at $p$-value $\leq 0.05$. And number of abortion also shows significant association with teachers' knowledge at $p$-value $\leq 0.01$. The number of stillbirth and type of delivery show no significant association with knowledge, and there is no significant association between teachers' knowledge with remaining variables.

\section{Discussion}

The present study reveals that the highest percentage (37.5\%) their age is ranged between (21-30). Samira et al., 2015 has determine that the mean age of participants is (30.4) years is ranged 16-65 years of age group in Gabonese women ${ }^{(5)}$. The present study shows the highest percentage $(80 \%)$ are graduated from college. This result is disagree with Al-Meer et al., 2011 among practices of Qatari women was (57.8\%) were graduated from college and shows that the highest percentage $(25 \%)$ was graduated from primary school. (42.5\%), (10\%) are graduate from secondary School. (22.5\%) are graduate from university. This result is disagree with Al-Meer et al., (2011) among practices of Qatari women found that (23.6\%) are graduate from primary school. (57\%) are graduate from secondary School and $(52.8 \%)$ are graduate from University ${ }^{(6)}$. The 
present study shows that the highest percentage (85.0\%) is married. This result is disagree with Amosu et al. (2011) among women in Osun state Nigeria found that $(77.4 \%)$ was married ${ }^{(7)}$. The present study shows that: $(20 \%)$ has enough monthly income , $(67.5 \%)$ enough in some extend , (12.5\%) does not have enough monthly .In Egypt Doaa et al.,(2014) states that economic status(56\%) has enough monthly income while (44.9\%) does not have enough monthly income ${ }^{(8)}$. The present study shows that Number of gravid has primigravida is (30\%), $2-4$ pregnancies have $(60 \%)$, and 5 pregnancies and more are (10\%). This result disagrees with Sadat et al. (2013) in Tanta City who has found that primigravida has (62.9\%), 2-4 pregnancies has (31.5\%), 5 pregnancies and more are $(5.6 \%){ }^{(9)}$. The present study shows that the highest percentage $(2.5 \%)$ has null pregnancy, $(40 \%)$ has one, $(52.5 \%)$ that (2-4) has pregnancy. This result is disagree with El-Moselhy et al.,(2016) Al-Hussein and Tanta University Hospitals; among Adult Egyptian Females who has found that has null pregnancy is $(3.5 \%),(9.0 \%)$ and has $2-4$ is $(49.5 \%)(34.0 \%){ }^{(10)}$. The present study shows that the highest percentage $(82.5 \%)$ doesn't have previous abortion. (17.5\%) have (once) time previous abortion. This result disagrees with study by Al-Meer et al., (2008) among Qatari women that has found (67.8\%) do not have previous abortion and $\left(17.4 \%\right.$ ) have (once) time previous abortion ${ }^{(6)}$. The present study shows that the highest percentage (74\%) does not have still birth. (22.5\%) have (once) still birth and (2.5\%) have (two) still birth. This result disagrees with Neriman et al., (2013) total of participant who have still birth is $(6.2 \%)$ among women in Izmir ${ }^{(\mathbf{1 1})}$. The present study shows that the highest percentage $(2.5 \%)$ does not have child. $(87.5 \%)$ have child from (1-3). (7.5\%) have child from 4- 6. (2.5\%) have 7 children and more. This result disagreeing with Richard (2006) who has found that $(25.9 \%)$ do not have a child. (25\%) those have children from $1-3$. $(49.2 \%)$ those have 7 children and more ${ }^{(\mathbf{1 2})}$. The highest percentages $(95 \%)$ have hospital delivery and $(5 \%)$ have home delivery.The present study shows that the highest percentage (20\%) Cesarean section delivery. $(80 \%)$ has normal vaginal delivery. This study disagreed with El-Moselhy et al., (2016) Al-Hussein and Tanta University Hospitals, among Adult Egyptian Females has found that: (98.8\%), (87.4\%) have normal vaginal delivery. $(1.2 \%)(12.6 \%)$ have Cesarean section delivery ${ }^{(10)}$. Knowledge is very inadequate in the domain of anatomy \& physiology of cervix with the highest percentage (30\%)and grand mean(1.1) have knowledge regarding to anatomy and physiology of cervix this result dis agreed with Nootan et al., (2014) ${ }^{(13)}$. The present study shows that the highest percentage Knowledge of teacher's regarding signs and symptoms of cervical cancer are Bleeding between cycle, lower back pain and Offensive odder of discharge is (10\%) with grand mean (1.1) who have knowledge.This result disagreeing with Abdul-Aziz al.,(2006) ${ }^{(\mathbf{1 4})}$. In present study showed that the highest percentage (20\%) (1.1) know that Positive and negative smoking may increase risk of cervical cancer, and knowledge of Hormonal contraceptive methods used is a risk to develop cervical cancer is( $10 \%)$ with grand mean . This study disagrees with Juana et al., (2013) ${ }^{(15)}$. The present study shows that pap smears uptake among teachers represented the highest percentage (30\%) with grand mean (1.3) have heard of Pap smear with mean of score (1.3) . This result was disagree with A study conducted by Hyacinth et al., (2012) (16). The percentage is $(10 \%)$ with grand mean (1.3), related to frequent visit to clinics to make Pap smear. The percent result disagrees with sedighe et al., (2012) ${ }^{(17)}$.

The percent study reaches to $(10 \%)$ of knowledge percentage concerning in related to age performing with grand mean( 1.3) something that disagrees with Aynur et al., (2009) ${ }^{(18)}$. The present study shows the highest result of detecting precarcenoma cells percentage the results shows that (10\%) with grand mean(1.3).This result disagrees with a study made by Mark et al., (1998) ${ }^{(19)}$. The present study finds out that the highest percentage had a lack of knowledge related to cervical cancer). This result disagrees with that of Hlengiwe. (2011) ${ }^{(\mathbf{2 0})}$. The present study shows that the highest percentage (90\%) with grand mean (1.3) Don't have time to do pap. This result disagrees with Cathrin et al., (2015) ${ }^{(21)}$. The present study shows that the highest percentage 10\% with grand mean (1.3) of Pap smear is expensive, this result was disagreeing with Anne (22,23). The present study show that the highest percentage is $100 \%$ with grand mean (1.3) did not have knowledge of Pap smear to detect precancerous cells. This result disagree with sedighe et al., (2012) ${ }^{(17)}$. The present study shows that the highest percentage (100\%) with grand mean (1.3) to women's did not awareness of the Pap smear ability to detect the fibroid tumor.The later result disagrees with sedighe et al., (2012) ${ }^{(17)}$. The present study shows that the highest percentage (100\%) with grand mean (1) is to the lack of knowledge of Pap smear ability of reducing mortality and morbidity caused by cervical cancer. This result disagrees with sedighe et al.,(2012) ${ }^{(17)}$. The present study shows that the highest percentage $(100 \%)$ with grand mean (1.3) is the lack of knowledge of doing pap smear at the onset of marriage. The result of this study disagrees with Shyamala et al. (2014) ${ }^{(24)}$. The present study mentions that the highest percentage( $\left.100 \%\right)$ with grand mean (1.3) is of lacking the knowledge of Pap smear doing at age 21 years for married woman .This result was disagree with Shyamala et al., (2014) ${ }^{(24)}$. The present study shows that the highest percentage (10\%) with grand mean (1.3) have knowledge of Performing pap smear every 3 years . This result disagrees Fauziah et al. $(2011)^{(25,26)}$. The present study shows that the highest percentage $(10 \%)$ with grand mean (1.3) have knowledge that of Pap is a method of cervical cancer prevention. This result was disagrees with Cathrin et al.,( 2015) (17,21). The present study shows that the highest percentage $(40 \%)$ with grand mean $(1.3)$ have knowledge of 
Pap ability to detect infection of the reproductive system .This result disagrees with Nesreen et al.,(2015) (27). The present study show that the highest (40\%) with score of mean (1.3) have knowledge of Colposcopy as a way for the doctor to use special magnifying device to look through vagina .This result disagrees with Marian et al., (2002) ${ }^{(28)}$. The present study shows that the highest (40\%) with grand mean(1.3) have knowledge of Using speculum to open vagina and observe cervix .This result disagrees with Shyamala et al.,(2014) ${ }^{(24)}$. The present study shows that the highest percentage (30\%) with grand mean (1.3) have knowledge of Using iodine to stain the every normal cells expect the carcinoma .This result was disagree with Cathrin et al., (2012) (21,24). The present study shows that the highest $(80 \%)$ with score of mean (1.2) have knowledge of eating balance diet to maintain woman's health. This result was disagree with Yao Jia et al.,(2013) ${ }^{(29)}$. The present study shows that the lack knowledge of participant of Performing Pap test regularly even in well health is $(100 \%)$. This result disagrees with Juana et al., $(2013)^{(30)}$. The present study shows that the highest percentage (30\%) with grand mean (1.3) have knowledge of HPV Vaccination in case of availability .This result disagrees with Dolar et al.,(2014) ${ }^{(31)}$. There is no significant association between age group and knowledge of cervical cancer. This result agrees with the study by Gol (2009) there are no significant differences between knowledge of nurses of cervical cancer or symptoms and screening methods ${ }^{(32)}$. Regarding the marital status: there is no significant association between material status and knowledge of cervical cancer. This result was disagree with Al-Dubai et al., (2010) who has reported that marital status is the only socio-demographic factor significantly predicting the level of knowledge among Iranian women who are living in Malaysia ${ }^{(33)}$. Regarding the level of education in present study shows no significant association between level of education and knowledge.This result disagreeing with Holcomb et al., (2004) in which level of education had positive association with knowledge ${ }^{(34)}$. There is no significant association between economic statuses and knowledge. Marian Ret al.(2002) has found that significant association between knowledge and reproductive health status regarding to cervical cancer screening at $(\mathrm{p}=0.002){ }^{(28)}$. Regarding Reproductive health status there is no significant association between knowledge and Reproductive health status. Marian et al., (2002) has found out a significant association between knowledge and Reproductive health status regarding to cervical cancer screening at $(\mathrm{P}=$ $0.002)^{(28)}$.

\section{Conclusion And Recommendations}

Conclusion: The study was concluded that most of the items of knowledge related to cervical cancer were below cut-of-point (1.5)

\section{Recommendations:}

1. Increase women awareness of cervical cancer through mass media.

2. Establish a lectures or courses to raise awareness of teacher's at secondary school about cervical cancer.

3. Work the training session for teachers about cervical cancer through utilization poster and another tool to explain the cervical cancer.

\section{Reference}

[1]. Roland, K.; Bernard, V.; Saraiya, M.; Hawkins, N.; Brandit, H. and Friedman, A.: Assessing cervical cancer screening guideline in patient education materials. Journal of women's Health, 2009, 18 (1), p.p. 5-12.

[2]. Balogun, M.; Odukoya, O.; Oyediran, M. and Ujomu, P.: Cervical Cancer Awareness and Preventive Practices: A Challenge for Female Urban Slum Dwellers in Lagos, Nigeria. African Journal Reprot Health, 2012, p.p. 16, 75-82.

[3]. Powe, B.: Perception of cancer fatalism and cancer knowledge: A comparison of younger and older African American women. Journal of psychological oncology. 2006, 24 (3) p.p.11-20.

[4]. Vandana, M.; Vani, C.; Balachandran, A.; Vani, C. Balachandran, V.: Pap smear. Indian Journal Dermatol Venereol Leprol, 2009, p.p. 75:214-6.

[5]. Samira, Z.; Assoumou, P.; Barthelme, M.; M.; Angelique, N.; Mustapha, M.; Abdelkim, K. and Mustapha, E.: Awareness and knowledge regarding of cervical cancer, Pap smear screening and human papillomavirus infection in Gabonese women. Women's Health, 2015, p.p. 15-37.

[6]. AL-Meer, F.; Aseel, M.; Al-Khalaf, J.; Al-Kuwari, M. and Ismail, M.: Knowledge, Attitude and Practices Regarding Cervical Cancer and Screening among Women Visiting Primary Health Care in Qatar. Eastern Mediterranean Health Journal, 2011, 17 (11), p.p. 855-861.

[7]. Amosu, A.; Degun, A.; Babalola, A. and Thomas, M.: Level of Specific Knowledge, Awareness, Perception, and Screening Behaviour Regarding Carcinoma of the Cervix among Rural Women in Iwo local government area, Osun State, Nigeria. Annals of Biological Research, 2011, 2 (2), p.p. 206-221.

[8]. Doaa, M.; Shisha, E.; Mansour, Nahed, F.; Kheder, M.; Mohammad, A.: Accuracy of Visual Inspection with Acetic Acid in Cervical Ectopy Evaluation. Journal of Nursing Education and Practice, 2016, 6 (3), p.p. 343-534.

[9]. Saadat Parhizkar .;Latiffah Abdul Latiff.; Mojgan Afshari .: Disseminating Cervical Cancer Knowledge: Impact of a Public Seminar , International Journal of Learning \& Development, 2013,1(3): 2164-4063

[10]. El-Moselhy EA1,Borg HM and Atlam SA.; Cervical Cancer: Sociodemographic and Clinical Risk Factors among Adult Egyptian Females, 1 ( 1):1-7

[11]. Neriman, S.; Birsen, K.; Saydam, Z.; Hafize, O.; Can1, V.; Aytül, H. and Ozlem, D.: Assessment of Cervical Cancer Risk in Women between 15 and 49 Years of Age: Case of Izmir. Asian Pacific Journal of Cancer Prevention, 2013, 1 (4), p.p. 14-21-39.

[12]. Richard, C.; Yang, P.; Mills, K. and Jennifer, L.: Cancer Screening, Reproductive History, Socioeconomic Status, and Anticipated Cancer-related Behavior among Hmong Adults. Asian Pacific Journal of Cancer Prevention, 2006, 3 (7), p.p. 20-29. 
[13]. Nootan, R.; Mali, M. and Ramling, M.: Effect of Structured Education on Knowledge Regarding Prevention of Cervical Cancer among A.N.M. Students. International Journal of Science and Research (IJSR), 2014, 3 (3), p.p. 18-27.

[14]. Abdulaziz, S.; Aldhafar, A.; Abdulhmeed, A.; Alhulaybi, I. and Talha, M.: Knowledge, Early Signs and Symptoms, Risk Factors and Prevention of Cervical Cancer among Teachers in the Urban Schools in Al-Ahsa, Kingdom of Saudi Arabia. International Journal of Scientific Study, 2006, 4 (3), p.p. 13-18.

[15]. Juanna, S.; Piyanee, K.; and Sandra, M.: Young Singaporean Women's Knowledge of Cervical Cancer and Pap Smear Screening: A descriptive study. Journal of Clinical Nursing, p.p. 2013, 22- 3310-3319.

[16]. Hyacinth, H.; Oluwatoyosi, A.; Adekeye, J.; Ibeh, N. and Tolulope, O.: Cervical Cancer and Pap Smear Awareness and Utilization of Pap Smear Test among Federal Civil Servants in North Central Nigeria. 2012, 7 (10), p.p. 46-583. Avialable at: www.plosone.org

[17]. Sedighe Rezaie-Chamani; B.Sc., Sakineh Mohammad-Alizadeh-Charandabi; Ph.D., Mahin Kamalifard; M.Sc. .: Knowledge, Attitudes and Practice about Pap Smear among Women Reffering to A Public Hospital, Journal of Family and Reproductive Health , 2012,4(6):177-182

[18]. Aynur Uysal and Aylin Birsel.: Knowledge about Cervical Cancer Risk Factors and Pap Testing Behaviour among Turkish Women, Asian Pacific J Cancer Prev,2009, 10, 345-350

[19]. Mark, B.; Dignan, R.; Bradlly, W.; Penny, S.; Douglas, C.; Ronny, B.; Joseph, K.; Stephen, D. and Richard, P.: Health Education to Increase Screening for Cervical Cancer among Lumbee Indian Women in North Carolina. Oxford University Press, 1998, 13 (4), p.p. 545-556.

[20]. Beauty Hlengiwe Ndlovu .: awearness ,knowledge and experiencesof women regarding cervical cancer in rural kwazulu-natal,south african ,Stellenbosch University ,2011:26-81

[21]. Catherine M. Kress.: Knowledge, attitudes, and practices regarding cervical cancer and screening among Ethiopian health care workers, International Journal of Women's Health, 2015,(7): 765-772

[22]. Anee Tiffy Sealy.: A Salon-based cervical cancer education project: A mixed-methods study conducted in trianded and Tobago , University of the West Indies, Trinidad and Tobago,2005:1-146

[23]. Carmen, R.; Heidi C. Pearson and Daniel M. Breitkopf.; By Carmen Radecki Breitkopf, Heidi C. Pearson and Daniel M. Breitkopf, Perspectives on Sexual and Reproductive Health, 2005, 37(2):78-84

[24]. Shyamala Devi .; Vijai Anand Babu .; Dara Aruna Kumari .: Nursing staff awareness of cervical cancer and pap smear screening in a remote medical college hospital in South India, International Journal of Research in Health Sciences, 2014,4 (2):1085-1090

[25]. Fauziah Abdullah1.; Norlaili Abdul Aziz.; Tin Tin Su.: Factors Related to Poor Practice of Pap Smear Screening among Secondary School Teachers in Malaysia, Asian Pacific J Cancer Prev,2011, (12): 1347-1352

[26]. Yupin Phianmongkhol , Nuttawan Suwan1, Jatupol Srisomboon2, Chumnan Kietpeerakool.: Knowledge about Human Papillomavirus Infection and Cervical Cancer Prevention among Nurses in Chiang Mai University Hospital, Thailand, Asian Pacific J Cancer Prev,2011 (12): 823-825

[27]. Nisreen Arif Al-bizrah ;; Farzana Rizwan Arain.: Knowledge and attitude about cervical screening and HPV vaccine among female medical students of Taif university, International Journal of Current Research and academic review, 2015,8(3):106-112

[28]. Marian, P. and Tracy, C.: Human Papillomavirus Infections and Risks of Cervical Cancer: what do women know?. Health Education Research, 2002 (17) (6), p.p.706-714.2002.

[29]. Yao Jia1., Shuang Li1., Ru Yang1., Hang Zhou1, Qunying Xiang2, Ting Hu1, Qinghua Zhang1, Zhilan Chen1, Ding Ma1*, Ling Feng1.: Knowledge about Cervical Cancer and Barriers of Screening Program among Women in Wufeng County, a High-Incidence Region of Cervical Cancer in China, Goli Samimi, Kinghorn Cancer Centre, Garvan Institute of Medical Research, Australia, 2013,7 ( 8 ):3-7

[30]. Juanna, S.; Piyanee, K.; and Sandra, M.: Young Singaporean Women's Knowledge of Cervical Cancer and Pap Smear Screening: A descriptive study. Journal of Clinical Nursing, p.p. 2013, 22- 3310-3319

[31]. Dolar, B.; Srikanth, R.; Karunakar, P. and Kopparesh, D.: HPV, Cervical Cancer and Pap Test Related Knowledge Among a Sample of Female Dental Students in India. Asian Pacific Journal of Cancer Prevention, 2015, 1 (6), p.p. 152 - 179.

[32]. Gul, E.: Awareness of Cervical Cancer Risk Factors and Screening Behaviour among Nurses in a Rural Region of Turkey. Asian Pacific Journal of Cancer Prevention, 2009, 10 (5), p.p. 20- 29.

[33]. AL-Dubai, S.; Alshagga, M. and Al-Naggar, R.: Knowledge, Attitudes and Barriers for Human Papilloma Virus Vaccines among Malaysian Women. Asian Pac Journal Cancer Preventive, 2010, p.p. 11, 887-92.

[34]. Holcomb, B.; J.M. Bailey; K Crawford and D.I. Bernstein, Attitudes about human M.T. Ruffin, Adult's knowledge and papillomavirus vaccine in young women. behaviours related to Human papillomavirus, International Journal of STD and AIDS, infection. JAM Board Fam pract, 2003, 17: 26-31. 